\title{
Distributed Leadership in Educational Institutions
}

\author{
Süleyman Göksoy \\ Correspondence: Süleyman Göksoy, Faculty of Education, Educational Sciences, Educational Administration and \\ Supervision, University of Düzce, 81620, Düzce, Turkey
}

Received: May 4, 2015 Accepted: May 21, 2015 Online Published: June 2, 2015

doi:10.11114/jets.v3i4.851

URL: http://dx.doi.org/10.11114/jets.v3i4.851

\begin{abstract}
In recent years, many studies are conducted about shared leadership process. Distributed leadership (DL) approach addresses leadership along with teams, groups and organizational characteristics. In practice, this approach objects the supposition that an individual should take the lead in order to ensure change. Proponents of this idea claim that shared leadership is required since educational institutions are too complex to be managed with only one individual. Responsibility for managing various complex tasks in organizations is distributed among a myriad of individuals with different roles. The basic principle advocated in this approach is based on the futility of efforts to ascertain a series of best single leader characteristics or best single leader behaviors. Current study aims to provide information on distributed leadership and discuss the applicability of the concept in educational organizations.
\end{abstract}

Keywords: educational organizations, leadership, distributed leadership

\section{Introduction}

Although investigations on leadership concept date back to Plato's "The Republic" written in 400 B.C. and thousands of studies, books and movies exist on the topic due to its importance which are designed to relate what is leadership and how to be a good leader, there are still areas that are uncovered about the concept (Lunenburg \& Ornstein, 2013).

In definitions of traditional leadership, leadership is defined as the process of influencing a group to reach goals (Robbins, 1994). That is to say, when observers are affected by a single individual in the realization of aims, it is claimed that leadership process is in effect (Birdal \& Aydemir, 1992) in this situation. Therefore, the essence of traditional leadership process consists of one individual's effect on others (Koçel, 1999). Leader in this leadership process is accepted as the person with the most or highest effect on the members of the group and defined as the individual with the highest impact on individuals or groups (Freadman, Sears \& Carlsmith, 2003:539) and as the individual who leads others to act in a specific way for a specific purpose (Hitt et. al., 1975; Ertürk, 2000).

Recent distributed leadership approach can be said to fully change even ignore the traditional leadership and leader definitions since leadership in distributed leadership approach has a more complex structure than leadership behaviors (Harris \& Lambert ,2003; Leithwood, Day et. al, 2006). Leadership structure and effective leadership practices are combined in four categories: identification of targets, development of individuals, reconstituting the organizational structure and improving teaching and educational program (Malloy, 2012).

Distributed leadership is a result of reflecting the cognizance on organizational management regarding the view that leadership roles and positions should be shared. That is to say, distributed leadership addresses the entirety of human resources in organizations, especially the academic staff in educational organizations as leaders. According to this leadership model, it is fundamental to develop leadership potentials of human resources at schools and provide equal chances and statuses for the staff to realize the goals of the school. The basic philosophy underlining this approach is the mobilization of shared wisdom and common sense by creating synergy among the staff at organizations and maximization of organizational efficiency, productivity and competence which will ensure achievement and happiness in the members of the organization. Distributed leadership model regards the management and operations of organizations in general and school organizations in particular as complex and complicated processes. Therefore, school management, which is a complicated and hard task, cannot be left to a single leader or leadership approach or potential because school structures are not easy to be managed effectively with the leadership of a single person.

\subsection{Developmental Process of Leadership Approaches}

Starting with the second half of the $20^{\text {th }}$ century, scientific studies on leadership have focused on the characteristics that 
separate leaders from non-leaders and leaders from their followers (Hoy \& Miskel,2012) and effective leaders from ineffective leaders. Trait theory, the first of leadership theories, proposes the behaviors that separate leaders from non-leaders (Robbins \& Judge, 2012). Studies have presented many personal characteristics of leaders (Bass, 1990). In fact, the main element that highlights a single person as the leader is the personal characteristics. Especially the psychological and physiological properties of the leader have become the focus of these studies (Şişman, 2002; Çelik, 1999; Erdoğan, 1991; Stogdill, 1948, 1981; Immegart, 1988).

In the 70's, there was still no consensus as a result of trait theory about constant personality and physical properties of a leader that would be pertinent in all situations (Kızıloğlu, Tabak, Erkeneli, 2012). Behavioral theory which seeks the answer to the question "What makes a leader effective?" in types of leader behaviors started to attract researchers' attention since the ' $70 \mathrm{~s}$. Studies in the realm of behavioral approaches generally focus on leadership behaviors, leadership styles as behavioral patterns and their potential effects of groups (Erçetin, 2000).

According to behavioral leadership theory, attitudes and behaviors of leaders towards their followers are crucial for success. Based on this theory, leadership is a behavioral process in role systems. The leader mainly depends on the resources of persons, feels responsibility towards these individuals and utilizes interactions with them to obtain the desired outcome.(Werner, 1993). In the theory, leadership behaviors are based on two different dimensions. While one dimension is related to individuals, interpersonal interactions and the continuity of the group, the other is based on production orientation and realization of goals (Cartwright \& Zander, 1953). Therefore, the approach includes leadership styles that focus on interpersonal relationships, consider personal needs of staff and regard differences among members and the leadership styles that focus on the technique and content of tasks (Robbins and Judge, 2012).

The last two theories in leadership theories are contingency/situational leadership and full-range theory of leadership. In situational leadership theory, it is believed that circumstances require different leadership styles and situations create the leader (Hoy \& Miskel, 1991). Contingency theories purport that there is not a single leadership style that is effective in all cases and leadership style changes according to situations (Arun, 2008).

Situational/contingency theory which states that it is impossible to predict effective leadership behaviors for different situations and that there is not a single most effective leadership style for all cases (Şimşek, 2010; Çelik, 1999) aims to identify the distinctive characteristics of environments that may be the source of leader success and to distinguish between the characteristics of leadership situations related to leader behavior and leader performance (Campbell et. al., 1970; Lawler, 1985; Vecchio, 1993). Contingency either increase or limits the effect of the leader (Hoy \& Miskel,2012). From a different standpoint, contingency theory should also focus on the audience. Contingency theories assume that selection of leadership style based on the characteristics of the task that the audience desires or the perceptions of audience will determine the success levels of the leader (Robbins \& Judge, 2012).

\section{2 Modern Leadership Approaches and Distributed Leadership}

Almost a hundred new leadership theories were developed or proposed in the last phase in leadership studies which is addressed as modern/new or full-range leadership theories. The main modern leadership theories include implicit leadership, strategic leadership, online leadership, selfleadership, servant leadership, authentic leadership, transformational leadership, charismatic leadership, synergic leadership, substituted leadership, mentoring, transactional leadership (Bass, 1985; Lunenburg and Ornstein, 2013; Hoy and Miskel,2012; Tabak, Şeşen,Türköz, 2012), shared leadership (Bakır, 2013; Bostanc1, 2012), distributed leadership (Spillane \& Diamond, 2007; Gronn, 2002; Baloğlu, 2011; Korkmaz \& Gündüz, 2011; Özer \& Beycioğlu, 2013; Hulpia, Devos \& Rosseel, 2009; Özdemir, 2012; Elmore, 2000), ethical leadership, cultural leadership, instructional leadership, learning leadership, visionary leadership, charismatic leadership (Çelik, 1999; Şişman, 2002).

Situational leadership and newer leadership theories explain the distribution og leadership functions with concepts such as distributed cognition (Halverson, Clifford, 2013; Brown, 1989), democratic leadership (Bass, 1990), shared leadership (Kocolowski, 2010; Judge \& Ryman, 2001; Sergiovanni, 1995) and selfleadership (Charles, 1986; Uğurluoğlu, 2010). Distributed cognition (Halverson, Clifford, 2013; Brown, 1989) is another theory related to distributed leadership according to Printty (2008) and it represents collective intellect. Here, knowledge, skill or expertise is more than the sum of individualistic knowledge and abilities. There is a possible choreography comprehended collectively which creates the group intellect. This is sometimes called organizational knowledge and sometimes it is addressed as learning. The concept expresses the expansion of knowledge across people and cases. Since interactions among leaders, audience and situations are crucial in distributed leadership, distributed leadership is very close to distributed cognition. In this perspective, leadership generates the collective leadership potential of an organization and leadership is more than individualistic knowledge and skills (Baloğlu, 2011).

Shared leadership construct is conceptualized as democratic leadership (Bass, 1990) or participative leadership (Robbins and Judge, 2012). However, in essence distributed leadership is not synonymous to cooperative or participative leadership 
approaches although they are similar. It is stated that distributed leadership is a leadership approaches that contains a larger meaning than the concepts included in democratic or participative leadership (Davis, 2009, cited in: Baloğlu, N. 2011). Participative leadership emphasizes the importance of decision processes as well as the decisions selected for implementation by the leader. Democratic leadership approach allows group discussions and emphasizes making group decisions (Şimşek, 2010). Participative leadership model developed by Victor Vroom \& Phillip Yetton (1973) examines participation and leadership behaviors together in decision making processes. The approach also called leader participation model proposes rules about the style and degree of participation in decision making in different situations.

The basic premise behind participation is the belief that individuals will adopt and support the decisions when they are involved in decision making (Sabuncuoğlu \& Tüz, 1996:137; Eren, 1993:167). Participating in administrative decision making may positively or negatively affect staff behavior in educational organizations (Motowidlo, 1996). Studies show that bigger impact is achieved in teaching when the number of teachers participating in decision making mechanisms is higher (Moore \& Esselman, 1992). Similarly, results of many studies point to the fact that organizations in which employers only behave according to legal rules carry higher risks for failure (Katz, 1964, Katz \& Kahn,1966).

Spillane \& Diamond (2007) describes distributed leadership as collaborated and collective and coordinated distribution. The important characteristic of distributed leadership is based on the distribution of leadership between formal and informal leaders. Shared leadership in distributed leadership does not signify how an individual undertakes a specific task compared to others. Sharing leadership is related to what the individuals in the leadership group contribute to the knowledge pool (Gronn, 2002; Korkmaz \& Gündüz, 2011).

In this sense, distributed leadership carries traces of other leadership theories that provide laissez-faire leadership and makes use of them. According to Eren (2001), laissez-faire leaders need management authority the least, leave their audiences on their own and allow their audiences to prepare goals, plans and programs in line with the resources provided to them. However, in their study, Hinkin \& Schriescheim (2008) assess this type of leadership as the most passive and ineffective type of leadership. Although active and passive management (even though there are exceptions) styles are regarded as better than laissez-faire leadership style, they are still accepted to be unproductive. In this approach, leaders are generally active when there are problems and that is more often too late to solve the problem (Hoy \& Miskel,2012). Bass (1998) regards this type of leadership as lack of interaction with staff. An example of a laissez-faire leader would be the administrator who stays at the office all day, has the most limited interaction with students and staff, displays no interest in student development and teacher needs and allows everything to continue as before can be given as

Schlechty (2005) likens shared leadership to a jazz group which is led by one of the musicians depending on the rhythm at the moment rather constantly led by the maestro. This type of leadership requires paying attention to common commitments, beliefs and values. In the same study, Schlechty (2005) explains the distinction between shared and distributed leadership by stating that shared leadership does not mean equality or sharing of the administration role but it means sharing the decisions by the authorities regarding subordinates with the individuals in these units.

Self leadership/super leadership concept is the closest leadership concept to distributed leadership. Self leadership requires a radical paradigm shift in leadership theories. In all past or present leadership theories, the leader is accepted as the individual who influences the audience. Super leadership theory opposes this supposition. This theory allows everyone to be his/her own leader (Çelik, 1999:230). In self leadership, leaders receive their own energies from their won leadership styles. The new criteria for leaders in this approach is to accurately identify their won futures, recognize their own skills and competences and develop them to the highest possible level. As a matter of fact, teachers and textbooks are not the prerequisite of obtaining knowledge any more. Changes in the scope, quality and speed of knowledge are rapidly transforming learning and teaching processes. Teachers are assuming the role of facilitator, guide and empowering agent (Drucker, 1994).

According to Çelik (1999), everyone in organizational environments has the opportunity to become super leaders. However, super leadership requires a long term and continuous training. Based on this theory, school administrator is one of the individuals like the teachers who have the opportunity to become a super leader. The school administrator has not privilege over the teachers. Super leadership theory makes each teacher his/her own leader. School personnel can make the planning of their own careers during the super leadership process. According to this leadership approach, school administrators should first develop themselves and then train the teachers as super leaders. When the shared values of school culture are based on trusting a higher number of individuals and individualism, super leadership behaviors will develop in the school environment.

All these proposed leadership theories may be said to have been developed as a necessity or result of organizational or individual requirements since organizational change or transformation has necessitated and resulted in transformational leadership and ethical leadership was born as a result of cases in which ethical problems were experienced. Therefore, it 
can be claimed that the thesis of "situations create the leader" has proven itself with the new leadership theories. In this context, expectations and demands from schools are more comprehensive today and school principals cannot meet these demands on their own. In distributed leadership, principals and teachers share leadership roles as can be observed in teaching program meetings, coordinated professional development opportunities and work on relationships with the school community (Spillane, 2005). However, in order to accomplish that, teacher and principal roles need to be changed and transformed (Barth, 2001; DuFour \& Eaker, 1998).

Distributed leadership is the sharing and distributing of leadership practices (Malloy, 2012). Leaders and the audiences interact in this type of leadership (Spillane, 2006). Individual expertise is the focus of distributed leadership rather than position (Anderson, et. al., 2008; Bennet et. al., 2003; Heller \& Firestone, 1995; Malloy, 2012). Therefore, distributed leadership is not simply sharing tasks or assigning people to specific tasks (Penlington et. al., 2008). In this type of leadership, working for the same goals with continuous communication and interaction is emphasized rather than individual effort and it is possible for the staff to both collectively work and learn together (Halverson, 2007); such as developing the capacity of a teacher with the help of another teacher (Copeland, 2003). Therefore, distributed leadership has completely changed the traditional leadership model in which a single individual is the hero, the guide and the responsible party (Gronn, 2002) and allocated the leadership positions among the members of the organization (Malloy, 2012).

\subsection{Distributed Leadership}

Distributed leadership is not a new concept at all (Hoy \& Miskel,2012) and it is a leadership approach used since the '50s (Gibb 1954; Gronn, 2002). In educational sciences, researchers have started to focus on shared leadership since 1990 (Gronn, 2002). However, distributed leadership concept and approaches still continued to be explained under concepts such as "self leadership"/super leadership /shared leadership (Bostanc1, 2012).

Distributed leadership approach addresses leadership along with teams, groups and organizational characteristics. In practice, these approaches oppose the assumption that individuals should lead others in order to ensure change (Heller and Firestone, 1995; Hoy and Miskel,2012). Advocates of this idea argue that shared leadership is necessary since educational organizations are too complex to be led by a single person (Heller \& Firestone, 1995). Responsibility for managing a plentitude of complex tasks is distributed among many individuals and roles (Hoy \& Miskel,2012). The basic principle that the approach defends is based on the futility of efforts to ascertain a series of best single leader characteristics or best single leader behaviors. Modern researchers and school administrators believe that leadership practices are too complex to be represented by a single behavior series (Lunenburg \& Ornstein, 2013).

In their study titled "Building Leadership Capacity for School" presented as a reference in this field, Harris \& Lambert (2003) argues that conceptual and functional discussions related to distributed leadership are still ongoing and in spite of organizational learning studies of more than twenty years, there are still not clear identifications about how to adapt distributed leadership positions and roles to school practices and how the distributed leadership image should be in schools (Senge 1990, Louis \& Kruse 1995; Spillaneet et. al., 2001). As a result, it is observed that distributed leadership and leadership capacity is still regarded as an amorphous) concept. Harris \& Lambert (2003) have gone further to claim that inexistence of task distribution by the leader is a myth in distributed leadership since distributing tasks and duties as well as delegating positions is the most important power element in the leadership process.

The most important and striking element that separates distributed leadership form the other leadership concepts explained above is the fact that distributed leadership includes many elements related to education and is almost fed by educational environments. In this sense, Halverson, Clifford calls distributed leadership (2013) as distributed instructional leadership and defines the concept as generation of an effective leaning climate by the leaders for teachers and students.

Distributed leadership is shared school leadership. Shared school leadership is more than the sum of knowledge and actions of individual leaders. Structured courses selected as specific leadership actions are organized as a result of dynamic interaction between many leaders and audiences. School leadership is defined as the use of social, physical and cultural resources in order to obtain identity, acquisition, distinction, coordination and learning and teaching conditions (Spillane, Halverson, Diamond, 2001). Distributed leadership presents descriptive perspectives to schools that can lead them (Hoy \& Miskel, 2012). As a matter of fact, leadership includes activities directed at provision and continuance of positive learning climates in which teaching and assessment activities are undertaken (Charles et. al., 1996).

Studies on distributed leadership which is a new instructional leadership model present the finding (Harris \& Lambert, 2003) that it is not possible to create a distributed leadership model without redesigning the school as an organization. Vision and values at schools also need to be transformed in this context. Mental processes of school staff in the line of "all students are intelligent and they can learn" may contribute to the formation of this type of leadership approach. According to Spillane et. al. (2001), distributed leadership approach carries leadership practices in schools to how social 
and situational structures should be reestablished. Distributed leadership is at the center of capacity for creativity. However, it is necessary to identify the impact of changes at schools and how these approaches can be transferred to practice at schools.

This argument (distributed leadership) will mentally give way to other questions. If leadership is a shared function, how it will be expressed and defined? Who will distribute leadership duties and who will organize them? It is believed that these questions will be clear following discussions. Secondary crucial important issue is becoming our own leaders when we accept leadership which will create a close and dynamic relationship. Lastly, it is not possible to assign others in distributed leadership since there are tasks for all and everyone has equal authority and rights to undertake them.

Characteristics of distributed leadership (Özdemir, 2012; Gündüz \& Korkmaz, 2011, Baloğlu, 2011; Yılmaz, 2013; Bakır, 2013; Bostanc1, 2012; Özer \& Beycioğlu 2013; Gronn, 2000; Spillane, 2005; Elmore, 2000 Hulpia; Devos \& Rosseel, 2009) can be summarized as below:

The leader cannot be a single individual and leadership needs to be shared (Gibb, 1954).

This perspective regards leadership as the collective contribution of all leaders to the organization and therefore it is distinct from all other theories (Harris 2005a; Printy, 2008).

Leadership role is not assigned to an individual in the group; all members of the group undertake this function willingly as if it is their fundamental duty (Storey, 2004).

Distributed leadership is classified under two dimensions as adaptive and quantitative behaviors. Adaptive behavior is related to different units/departments in interaction to behave in a coordinated manner and quantitative behavior is related to the belief that all individuals in the organization can be leaders at some point (Gronn, 2002).

Distributed leadership is the distribution of tasks among the leader and the audience and integration of these tasks in the long run (Spillane et. al., 2001).

Distributed leadership can be said to focus on three themes: leadership is shaped as the common product of the group and as a result of interaction among individuals; borders in leadership are not definitive and strict, they are open-ended and diversity in practice is obtained with a part or even all of the members (Bolden et. al., 2009).

It is identified that a member can be assigned for duty in some leadership functions and that some leadership functions can be undertaken by different individuals at different times (Gronn, 2002; Yukl, 1999 ).

It is distributing organizational tasks to the entirety of the organization (Elmore, 2000).

It is related to distributing leadership functions to the members of the organization or the team instead of focusing on the hero concept which undertakes all leadership functions by himself/herself (Yukl, 2002).

Distributed leadership is born from cooperation as an important constituent of organizational life (Gronn 2002).

When leadership is distributed, power of formal leaders is not erased but each leader mutually strengthens the position of the other. There is a positive relationship between distribution of leadership and development of capacity (Baloğlu, 2011).

Leadership is created as a result of ties among individuals. With the help of distributed leadership, cooperation is created among the actions of individuals and leadership is realized in this manner (Spillane, 2006).

There is the belief that "it is better to distribute leadership among many people than for a single leader to act alone" (Kempster, Cope and Parry, 2010).

It is redistribution of power and rearranging authorities in the organization (Harris \& Muijs, 2005).

Distributed leadership is turning all types of products born from interaction to the common capital of the organization including knowledge by respecting different expertise areas and accepting them (Gündüz \& Korkmaz, 2011).

Distributed leadership is the guide and leading element for instructional development (Elmore, 2000).

It is very important for distributed leadership to create a climate in which learning is regarded as the "common good" for everyone's benefit (Elmore 2000).

It is a perceptive or cooperative decision making process that includes administrators, teachers, students and parents (Smylie, Lazarus \& Conyers, 1996).

It has more influence than the sum of all leaders and their efforts to arrive at a larger scale leadership behavior (Spillane, 2006).

Distributed leadership is based on expertise, knowledge and contributions created as a result of relationships network among individuals who direct, guide and work with teachers in the process of improving education (Davis, 2009).

Student achievement and orientation towards development in teaching are the foundations of distributed leadership (Chen et.al., 2007).

\section{Results}

Research showed that educators have positive views about the increases in student quality generated by distributed 
leadership (Mascall, et. al., 2009). First studies in the field presented that distributed leadership has crucial impact on learning conditions of the school (Leithwood \& Mascall, 2008). These and similar findings have resulted in focusing on distributed leadership concept. Although there are research findings pointing to positive effects of leadership on student achievement, experimental studies and studies on the applicability of distributed leadership are not comprehensive. Most of the studies focus on descriptions of the distributed leadership (Bennett, et. al., 2003; Gronn 2002; Harris, et. al., 2007; Harris \& Spillane, 2008; Leithwood et. al., 2008; Malloy, 2012). Therefore, limited number of studies discusses how to implement distributed leadership and how to transfer the concept to teaching and to student achievement.

As a result, distributed leadership approach claims that leadership at schools is a complex process that involves balancing technical and symbolic demands (Deal \& Peterson, 1994) and includes many elements (Hoy \& Miskel, 2012). In this context, tasks and duties at schools are courses of duties that are too multi dimensional and complex to be handled with a single person (school principal). Distribution of leadership at school is inevitable. Developing leadership potentials of each individual who is affected by school management and reflecting this potential to management is both an imperative and hard task. Maybe the most important and facilitating element in this stage is the organization and arrangement of leader-member interaction at school in the framework of the leadership process.

\section{References}

(1993). Management and Organization. Istanbul: Beta Basım ve Yayınevi.

(1995). Organizational Psychology. Bursa: Ezgi Kitapevi Yayınları, (1989). Psychology of Management. Istanbul: Business Faculty.

American Psychological Association. (1972). Ethical standards of psychologists. Washington, DC: American Psychological Association.

Anderson, S. E., Moore, S., \& Sun, J. (2008). Positioning the Principals in Patterns of School Leadership Distribution. In K. Leithwood, B. Mascall \& T. Strauss (Eds.), Distributed Leadership According to the Evidence. New York: Routledge.

Arun, K. (2008). Relationship between Leadership Styles and Shared Knowledge Culture. Unpublished Doctorate Thesis, Atatürk University, SBE. Erzurum.

Bakır, A., A. (2013). Analysis of the relationship between teachers' perceptions in shared leadership and organizational commitment. İnönü University Institute of Educational Sciences, Unpublished Doctorate Thesis, Malatya.

Baloğlu, N. (2011). Distributed Leadership: A leadership Approach that Needs to be Taken into Consideration at Schools Ahi Evran University Faculty of Education Journal, 12(3), 127-148.

Barth, R. (2001). Learning by heart. San Francisco, CA: Jossey-Bass.

Bass, B. M. (1990). Handbook of leadership: Theory, research and managerial applications. New York: Free Press.

Bennett, N., Harvey, J., Wise, C., \& Woods, P. (2003). Distributed Leadership, from www.ncsl.org.uk/literaturereviews

Birdal, İ., \&Aydemir, N. (1992), Management Theories, Istanbul.

Blase, J., \& Blase, J. (1999). Principals' Instructional Leadership and Teacher Development: Teachers' Perspectives. Educational Administration Quarterly. Thousand Oaks: Corwin Press.

Bolden, R., Petrov, G., \& Gosling, J. (2009). Distributed leadership in higher education. Educational Management Administration and Leadership, 37(2), 257-277. http://dx.doi.org/10.1177/1741143208100301

Bostanc1, A. B. (2012). Turkish Adaptation of Shared Leadership Perception Scale. International Journal of Human Sciences, 2(9), 1619-1632.

Brown, M. H. (1989). Organizing activity in the women's movement: An example of distributed leadership, international social movement research. Greenwich CT: JAI Press.

Campbell, J. P., Dunnette, M. D., Lawler, E. E. III., Karl, E., \& Weick, J. (1970). Managerial Behavior, Performance, and Effectiveness. New York: McGraw- Hill.

Cartwright, D., \& Zander, A. (1953). Group Dynamics: Research and Theory. Evanston, II. Row, Peterson.

Çelik, V. (1999). Educational Leadership. Ankara: Pegem.

Charles, C. M. (1986). Self- Leadership: Toward An Expanded Theory of Self-Influence Processes in Organizations. Academy of Management Review, 11(3), 589.

Charles, C. M., Senter, G. W., \& Barr, K. B. (1996). Building Classroom Discipline. Fifth Edition, USA Longman Publishers. 
Chen, G., Kirkman, B. L., Kanfer, R., Allen, D., \& Rosen, B. (2007). A multilevel study of leadership, empowerment, and performance in teams. Journal of Applied Psychology, 92 (2), 331-346. http://dx.doi.org/10.1037/0021-9010.92.2.331

Copeland, M. A. (2003). Leadership of Inquiry: Building and Sustaining Capacity for School Improvement. Educational Evaluation and Policy Analysis, 25(4), 375-395. http://dx.doi.org/10.3102/01623737025004375

Davis M.W. (2009). Distributed Leadership and School Performance. Dissertation Submitted to The faculty of The Graduate School of Education and Human Development of The George Washington University, UMI Number: 3344534.

Deal, T., E., \& Peterson, K., D. (1994). The Leadership Paradox. San Francisco, CA: Jossey- Bass.

Drucker, P. F. (1994). Yeni Gerçekler/New Truths. (Translator: B. Karanakçı) (4. Edition.) Ankara: İş Bankası Yayınları.

DuFour, R., \& Eaker, R. (1998). Professional learning communities at work: Best practices for enhancing student achievement. Bloomington, IN: National Education Service.

Elmore, R. F. (2000). Building a new structure for school leadership. Washington DC: The Albert Shanker Institute.

Erçetin, Ş. Ş. (2000). Vision in Leadership Helix. Ankara:Nobel Yayın Dağıtım

Erdoğan, İ. (1991). Behavior in Businesses, Istanbul: Istanbul University Faculty of Business Publications , 242.

Eren, E. (2001). organizational Behavior and Management Psychology, Istanbul, Betaş yayınları, Extended 7th Edition

Ertürk, M. (2000). Basic Principles of Business Science, Istanbul, Beta Basım, Yayım Dağıtım.

Freadman, A. İ. (1995). School Principal Burnout: The Concept and It's Components. Journal of Organizational Behavior, 16(2), 191-198. http://dx.doi.org/10.1002/job.4030160209

Freadman, J. L., Sears D. O., \& CarlSmith J. M. (2003). Social Psychology/Sosyal Psikoloji. (Tranlator: Ali Dönmez), Ankara: İmge Kitabevi,

Gibb, C. A. (1954). Leadership. G. Lindzey (Eds.). Handbook of Social Psychology, 2, 877-917. Reading, MA: Addison-Wesley.

Gronn , P. (2002). Distributed Leadership. K. Leithwood \& P. Hallinger (Eds.), Second International Handbook of Educational Leadership and Administration. Dordrecht; Boston: Kluwer Academic. http://dx.doi.org/10.1007/978-94-010-0375-9_23

Gronn, P. (2002). Distributed leadership as a unit of analysis. The Leadership Quarterly, 13, 423-45. http://dx.doi.org/10.1016/S1048-9843(02)00120-0

Güneş, F. (2010). Recent Developments in Educational Supervision and Constructive Approach, Educational Supervision Symposium Abstracts, Tem-Sen Yayınları, 9.

Halverson, R. (2007). Systems of Practice and Professional Community: The Adams Case. J. P. Spillane (Ed.), Distributed Leadership in Practice. New York: Teachers College Press.

Halverson, R., Clifford, M. (2013). Distributed Instructional Leadership in High Schools. http://website.education.wisc.edu/halverson/wp- content/uploads/2012/09/110411-Halverson-Clifford.pdf

Harris, A. (2005). Leading or misleading? Distributed leadership and school improvement. Journal of Curriculum Studies, 37(3), 255-265. http://dx.doi.org/10.1080/00220270500038602

Harris, A., \& Lambert, L. (2003). Building Leadership Capacity for School. Open University Press Maidenhead, Philadelphia, USA.

Harris, A., \& Muijs, D. (2005). Improving schools through teacher leadership. Maidenhead: Open University Press.

Harris, A., \& Spillane, J. (2008). Distributed Leadership Through the Looking Glass. Management in Education, 22(1), 31-34. http://dx.doi.org/10.1177/0892020607085623

Harris, A., Leithwood, K., Sammons, P., \& Hopkins, D. (2007). Distributed Leadership and Organizational Change. Journal of Educational Change, 8(4), 337-347. http://dx.doi.org/10.1007/s10833-007-9048-4

Heller, M. F., \& Firestone, W. A. (1995). Who's in Charge Here? Sources of Leadership for Change in Eight Schools. Elementary school Journal, 96(1), 65-86. http://dx.doi.org/10.1086/461815

Hinkin, T. R., \& Schriescheim, C., A. (2008). An Examination of Non-leadership: From Leadership to Leader Reward Omission and Punishment Omission. Journal of Applied Psychology 93(6).

Hitt, M. R., Dennis, M.R., \& Mathis, L. (1975). Effective Management, Hougron, Thierry, L'Analise de la ValeurOutil 
de Gestion, Les Edition d'Organisaiton, Paris.

Hoy, W. K., \& Miskel, G. C. (2012). Educational Administration, Theory, Research and Practice, (Translation editor: Selahattin Turan) Ankara, Nobel Yayınları 7. Edition.

Immegart, G. L., (1988). Leadership and Leader Behavior. N. J. Boyan (Ed.) Handbook of Research on Educational Administration (pp.259-77). New York:Longman.

Judge, W. Q., \& Ryman J. A. (2001). The shared leadership challenged in strategic alliances Lessons from the U.S. healthcare industry. The Academy of Management Executive, 15(2), 71-79. http://dx.doi.org/10.5465/AME.2001.4614907

Katz, D. (1964). The motivational basis of organizational behavior. Behavior Science, 9, 131-133.121 http://dx.doi.org/10.1002/bs.3830090206

Katz, D., \& Kahn, R. L. (1966). The social psychology of organizations. New York: Wiley.

Kempster, S., Cope, J. ve., \& Parry, K. (2010). Dimensions of distributed leadership in the same context. http://www.strath.ac.uk/media/departments/huntercentre/ research/workingpapers/WP10-1_Distributed_leadership_JC_v3.pdf.

Kızıloğlu, A., Tabak, A., \& Erkeneli, M. (2012). Implicit Leadership Theory. Modern Approaches in Leadership, Detay Yayıncılık, Ankara.

Koçel, T. (1999). Business Management, İstanbul, Arıkan Basım Yayın

Kocolowski, M. D. (2010). Shared leadership: Is it time for a change? Emerging Leadership Journeys, 3(1), 22-32.

Korkmaz, E., \& Gündüz, H. B. (2011). Primary School Administrators' Distributed Leadership Behavior Performance Levels. Kalem Eğitim ve Sağlık Hizmetleri A.Ş.

Lawler, E. E. III. (1985). Education, Management Style, and Organizational Effectiveness. Personnel Psychology, 38, 1-26. http://dx.doi.org/10.1111/j.1744-6570.1985.tb00538.x

Leithwood, K., \& Mascall, B. (2008). Collective Leadership Effects on Student Achievement. Educational Administration Quarterly, 44(4), 529-561. http://dx.doi.org/10.1177/0013161X08321221

Leithwood, K., Blair, M., \& Strauss, T. (2008). Distributed Leadership According to the Evidence. New York: Routledge.

Leithwood, K., Day, C., Sammons, P., Hopkins, D., \& Harris, A. (2006). Successful School Leadership: What it is and How it Influences Pupil Learning. :Department of Education and Skills.

Lunenburg, F. C., \& Ornstein, A. C. (2013). Educational Administration (Eğitim Yönetimi. Translation Editor: Gökhan Arastaman), Ankara, Nobel Yayınları 6. Edition.

Malloy, J. P. (2012). Effects of Distributed Leadership on Teachers' Academic Optimism and Student Achievement, Doctorate in Education, Department of Theory And Policy Studies Ontario Institute for Studies in Education of The University of Toronto.

Mascall, B., Leithwood, K., Strauss, T., \& Sacks, R. (2009). The Relationship Between Distributed Leadership and Teachers' Academic Optimism. In A. Harris (Ed.), Distributed Leadership. New York: Springer. http://dx.doi.org/10.1007/978-1-4020-9737-9_5

Moore, W., \& Esselman, M. (1992). Teacher efficacy, power, school climate and achievement: A desegregating district's experience. Paper presented at the Annual Meeting of the American Educational Research Association, San Francisco.

Motowidlo, S. J. (1996). Orientation toward the job and organization. K. R. Murphy (Edt.), Individual differences and behavior in organizations. (pp. 175-208). San Francisco: Jossey-Bass.

Özdemir, M. (2012). Turkish Adaptation of Distributed Leadership Inventory: Reliability and validity Studies. Educational Management in Theory and Practice, 18(4), 575-598.

Özer, N., Beycioğlu, K. (2013). Development of Shared Leadership Scale: reliability and Validity Work. Illkögretim Online, 12(1), 77-86. Web: http://ilkogretimonline. org.tr.

Özgür, U. (2010). Study on Self-leadership Strategies. Atatürk University Journal of Economics and Administrative Sciences, 24(1), 176-177.

Penlington, C., Kington, A., \& Day, C. (2008). Leadership in Improving Schools: a Qualitative Perspective. School Leadership \& Management, 28(1), 65 - 82. http://dx.doi.org/10.1080/13632430701800086 
Printy, S. (2008) Distributed Leadership: A Quick Tour of Theory and Practice, Michigan Principal's Fellowship. Michigan Principals Fellowship Summer Institute.

Robbins, S. P. (1986). Organizational Behavior: Concepts, Controversies and Applications. New Jersey: Prentice- Hall,

Robbins, S. P., \& Judge, T. A. (2012). Organizational Behavior/ Örgütsel Davranış (Translation Editor, İnci Erdem), 4. Edition, Ankara, Nobel Yayınc1lı.

Sabuncuoğlu, Z., \& Tüz, M. (1996). Organizational Psychology. Bursa: Ezgi Kitapevi Yayınları,

Schlechty P. C. (2005). Shaking Up The School House, Okulu yeniden Kurmak, (Çeviri, Yüksel Özden), ankara: Nobel Yayınları.

Senge, P. (1990). The Fifth Discipline: The Art and Practice of the Learning Organization. New York: Doubleday.

Şimşek, H. (2010), Total Quality Management, Theory, Principles, Practice. Ankara, Seçkin Yayıncıllk.

Şişman, M. (2002 ). Instructional Leadership. Ankara: Pegem A Yayıncılık.

Smylie, M. A., Lazarus, V., \& Conyers, J. B. (1996). Instructional outcomes of school-based participated decision-making. Educational Evaluation and Policy Analysis, 18(3), 181-198. http://dx.doi.org/10.3102/01623737018003181

Spillane, J. (2005). Distributed leadership. The Educational Forum, 69(2), 143-150. http://dx.doi.org/10.1080/00131720508984678

Spillane, J. P. (2006). Distributed Leadership (1st ed.). San Francisco: Jossey-Bass.

Spillane, J. P., \& Diamond, J. B. (2007). Distributed leadership in practice. New York: Teachers College Press.

Spillane, J. P., Halverson, R., \& Diamond, J. B. (2001). Investigating school leadership practice: A distributed perspective. Educational Researcher, 30(3), 23-28. http://dx.doi.org/10.3102/0013189X030003023

Stogdill, R., M. (1981). Traits of Leadership: A Follow-Up to 1970. In B.M. Bass (Ed.), Stogdill's Handbook of Leadership 8PP.73-97). New York: Free Press.

Storey, A. (2004). The problem of distributed leadership in schools. School Leadership and Management, 24(3), 249-265. http://dx.doi.org/10.1080/1363243042000266918

Tabak, A., Şeşen, H., \& Türköz, T. (2012). Modern Approaches in Leadership. Ankara: Detay Yayıncılık.

Vecchio, R. P. (1993). The Impact of Differences in subordinate and supervisor age on attitudes and performance. Psychology and Aging, 8(1), 112-19. http://dx.doi.org/10.1037/0882-7974.8.1.112

Vroom, V. H., \& Yetton, P. W. (1973). Leadership and Decision Making (Pittsburgh: University of Pittsburgh Press.

Werner, I. (1993). Leadership and Management, Personal development and Management Series: 1, Istanbul: Rota Yayın Yapım Tanıtım,

Yılmaz, A. İ. (2013). Shared Leadership Behaviors of Primary School Teachers. Dokuz Eylül University Institute of Educational Sciences, Unpublished Master's Thesis, İzmir.

Yukl, G. (2002). Leadership in organisations. New Jersey: Prentice Hall.

\section{$(\mathrm{Cc}) \mathrm{BY}$}

This work is licensed under a Creative Commons Attribution 3.0 License. 